ISSN: (Print) ISSN 1987-9601

(Online) E ISSN 1512-3146

Journal homepage: http://multilingualeducation.org/

\title{
Raising EU Awareness in Ethnic MinorityAreas \\ - Following the One Example of a Jean Monnet Project "Triangle Effect of European Studies at Schools" (TEESS)
}

\author{
Guranda Chelidze
}

Affiliate Professor of Caucasus university

Email: gchelidze@cu.edu.ge

\section{Ekaterine Kardava}

Associate Professor of Caucasus University

Email:ekardava@cu.edu.ge

\section{Zurab Bragvadze}

Professor of Caucasus University

Email: zbragvadze@cu.edu.ge

\begin{abstract}
To cite this article: Guranda Chelidze, Ekaterine Kardava \& Zurab Bragvadze (2021) Raising EU Awareness in Ethnic Minority Areas - Following the One Example of aJean Monnet Project "Triangle Effect of European Studies at Schools" (TEESS): International Journal of Multilingual Education, \#19; pp. 26-44.

DOI: $10.22333 /$ ijme.2021.19004
\end{abstract}

To link to this article: : https://doi.org/10.22333/ijme.2021.19004 


\title{
Raising EU Awareness in Ethnic Minority Areas - Following the One Example of a Jean Monnet Project „Triangle Effect of European Studies at Schools“ (TEESS)
}

\begin{abstract}
In the context of European Integration of Georgia, great importance is attached to the knowledge and expectations of the population, including the ethnic minorities, regarding Georgia's integration in the EU and implementation of the EU-Georgia Association Agreement. According to the surveys taken by various organizations, the popular mood in Georgia is positive where the EU-integration is concerned. Although the interest towards the association is substantial it does not rely on the specifics and dynamics of the bilateral relations. Mostly, the information the people get from the TV is superficial.

One option to raise the popular awareness is to implement the Caucasus University Erasmus + Jean Monnet "Triangle Effect of European Studies at Schools" (TEESS) project and share the university knowledge of European Studies with public schools. The project aims at raising awareness of the European integration, the Association Agreement and DCFTA in the regions densely populated by the IDPs, namely, the school children, teachers and their families.

The workshops staged in the Georgian, Russian, Armenian and Azeri public schools in the capital Tbilisi and the towns of Akhaltsikhe and Marneuli partly attended by the IDPs made the scarcity of the information and the interest evident. The discussions showed that most of them realized the importance of the EU support to Georgia. However, some of them were still skeptical. We suggest a different planning of the information campaign targeted at sharing the European values and generally the EU-Georgia relations, on the one hand and better instruction in the Georgian language in the regions populated with the ethnic minorities. The outcome of the project made it clear that supply of more comprehensive information on Europe at the history and civic education lessons to the school children could be a good option. That is what "The European Association Process in Georgia", a quadri-lingual textbook published within the frameworks of the Caucasus University "Erasmus +" Jean Monnet project funded by the Ministry of Education and Science of Georgia is targeted at. We suppose stepping up the project activities by adding elements of informal education and last but not the least, closer involvement of public agencies and institutions.
\end{abstract}

Key words: EU, TEESS, ethnic minority, awareness, public schools, handbook for history and civic education teachers.

\section{Introduction}

Georgia declared European Integration as a priority in its foreign and domestic policy from 1996. Following the successes in various areas, in 2014, Georgia and EU signed the 
Association Agreement and the one On the Deep and Comprehensive Free Trade Area (AA/DCFTA). Fulfillment of the obligations under the said Agreements, calls for substantial changes in nearly all the fields, the public support to the progress towards the EU and raising popular awareness of the European values. Every citizen should know how important the European integration and association are, and the prospects they open up.

There are ideological obstacles on Georgia's way to Europe created by the Russian Media propaganda, especially effective where the ethnic minorities, with their insufficient knowledge of the official language are concerned. The Internally Displaced People (IDPs) from Abkhazia and Samachablo (South Ossetia) are also prone to the Russian disinformation campaign.

The Georgian people, including the ethnic minorities should be well informed about the EU and implementation of the Association Agreement, so that they have a clear picture of what is in store for them. According to the surveys taken by various organizations, the popular sentiment is pro-European (www.epfound.ge); Although the interest in the association process is keen enough, the people are not fully aware of the specifics of the EU-Georgia relations and the dynamics thereof. It is mostly from TV that people get the information, which is far from sufficient.

Within the frameworks of Jean Monnet Project: "Triangle Effect of European Studies at Schools" (TEESS), we suggest introduction of European learning experience to public schools as a means of raising awareness of the European Integration, the Association Agreement and DCFTA among the IDPs students, teachers and their families by the professors of Caucasus University European Studies BA program, as well as the students and graduates.

\section{On the Caucasus University Erasmus+ Jean Monnet "Triangle Effect of European Studies at Schools" Project (TEESS)}

In order to enter the competition, the Caucasus University Erasmus+ Jean Monnet project "Triangle Effect of European Studies at Schools" (TEESS) was uploaded to the EC website in February 2019. In late July of the same year, we were supplied the information 
on the selection process and funding, and the formalities having been settled, the Project was launched on 14 November 2019.

Among others, TEESS involves workshops at the public schools. The target group is made up of the basic and secondary stage ethnic minority and IDP pupils of the public schools, their parents and teachers. The workshops mainly involve the teachers of history, civil education, geography, Georgian language and literature and foreign languages etc. interested academic staff. Each working meeting involved 55 students, teachers and parents. The workshops have been conducted in the public schools of Akhaltsikhe and Marneuli, as well as public school \#3 in Tbilisi of predominantly the IDPs pupils. All in all, over 500 beneficiaries have participated in the workshops.

TEESS was developed by the academic staff of the Caucasus University, BA Program of the European Studies of Caucasus School of Humanities and Social Sciences: Prof. Ekaterine Kardava and Prof. Guranda Chelidze. As to the training module, it was developed by the Project authors and experts, including Dr. of History, Prof. Zurab Bragvadze of the School of Humanities and Social Sciences.

Apart from raising awareness of the European association process, the workshops aim at motivation of the ethnic minority students to improve their proficiency in the Georgian language, so they are conducted in Georgian. Even more so, those after workshops, the students are supposed to enter "I Saw Europe in Georgia" essay competition; so sufficient knowledge of the official language matters a lot. In their essays to be written in the Georgian language, the students are going to impart their opinions on the significance of AA/DCFTA for the progress of the country, their personal development and the part they may play in creating a democratic society built on the European values. According to the Project curriculum, the competition is to follow the workshops, so that in the meantime, the non-Georgian students could improve their writing and communication skills.

We believe that the printed training materials handed out to the students and teachers are going to be helpful in terms of preparation to the essay competition. The same is true for "The European Association Process in Georgia" handbook for history and civic education teachers supported by the Georgian Ministry of Education, Science, Culture and 
Sports. To make it more accessible to the ethnic minorities, apart from Georgian and English, the handbook was translated into the Armenian and Azeri Languages (cu.edu.ge, 2021). The softcopies of the handbook were uploaded to the Caucasus University and the Project websites and posted on Facebook. The handbook was shared by several organizations also working on the European integration and association issues. The National Center for Teacher Professional Development, which reviewed the said manual approved and recommended it for instruction. The Center posted the relevant information in the Georgian and English languages (tpdc, 2021) on its web-portal. The handbook sets out the training materials, which meet the national curriculum standards of citizenship: student's knowledge of the public he/she is a member of and the local, national and global developments, as well as their implementation in practice. The workshops are going to help the students in terms of generating the sense of true citizenship, motivate them to take care of the country they live in, teach them the ways of civil involvement, make them realize that they can and should make a difference where the country (community/municipality or the state) is concerned; develop their collaboration, conflict settlement, entrepreneurial and financial management skills, make them focus on the human rights, tolerance, rule of law etc. democratic principles and motivate them for closer involvement in the public and political affairs (Citizenship - basic stage Standard). The handbook made up of three parts deals with the issues such as formation of the EU, its goals and tasks, European values, the EU expansion, progress of the EU-Georgia relations, the results of AA/DCFTA where the judiciary, labor relations, introduction of the EU market standards, food safety etc. issues are concerned. The authors of the handbook also speak about the cultural heritage issues within the frameworks of the EU-Georgia Association Agreement (Textbook, 2021).

The workshops have made it evident that the purpose of the project has been achieved: the teachers and pupils of the public schools in the regions densely populated by the ethnic minorities, as well as those of the IDPs schools have developed a new vision of association with the EU and importance of AA/DCFTA. The students realize how to get involved in building the society they are a part of and more of them support the national European Integration and Association policy. The number of Georgia's European integration 
supporters has increased. The ethnic minority school children are trying to improve their knowledge of Georgian.

However, the problems remain and we are going to touch upon them based on the trainings held at the public schools. We believe that meetings with school children and not infrequently with their teachers and parents for promotion of the EU and Georgia's integration in it are very important. Not only do those three groups get more comprehensive knowledge about Europe by listening to the trainers and doing exercises, but they also communicate and, sometimes, voice criticism at the seminars. All in all, it is a good way in terms of assessment of the environment they find themselves in.

\section{TEESS in Akhaltsikhe Public Schools}

We will start by saying in the first place that we found it quite difficult to implement the project in cooperation with other institutions.

The project was acknowledged with a high contest evaluation (88 points) by European Commission, but clearly stated goals and objectives in the project, the content of the planned workshops were not sufficient for starting practical activities in public schools without the relevant permission from the Ministry of Education, Science, Culture and Sports Affairs of Georgia. We would like to express our gratitude to National Department of Educational Plans, the management and experts of the Office of Assessment of National Educational Plans and Resources who exercised high consideration toward our project, provided their immediate support in acknowledgement of urgency and importance of teaching / promulgation of information about the European Union, the EU Association Agreement and the EU-Georgia Deep and Comprehensive Free Trade Agreement, although we had to rework the training module for admission to schools with consideration of the rules and requirements existing in Georgia. It is quite logical that it required a certain amount of time to learn, discuss, analyze and assess the module for the reason of which we received permission for its introduction to schools only on February 18, 2020. The process of negotiations with the local educational resource centers and school managements was started for agreement upon the time terms for the project 
implementation, but from March 2, 2020, the Covid-19 pandemic caused suspension of the educational process in public schools in Georgia to last till October. Even if the process resumed in the regions of Georgia where ethnical minorities form a part of the population, the educational resource centers, despite their sharing the opinion that conduction of the training was important, avoided admission of foreign persons into school buildings and conduction of similar activities. We, on our side, naturally treated this attitude with understanding, although on the other side, in view of the project time frames and the plan we had, were willing to start the process of the project practical implementation. On October 19-22, 2020, with the support provided by Akhaltsikhe region educational resource center, we were given the possibility to conduct four meetings in N1 Georgian, N6 Georgian, N3 Armenian and N2 Georgian-Russian public schools of Akhaltsikhe. The meetings were held in full compliance with the regulations of the Ministry of Healthcare of Georgia.

It should be underlined that the students of these schools and their parents as teachers showed great interest toward the training. In some of the schools the number of attendees even outnumbered the figures we had estimated which requires appreciation on our side. If we look at the statistics, the figures look as follows:

Chart 1. Attendance rate in schools

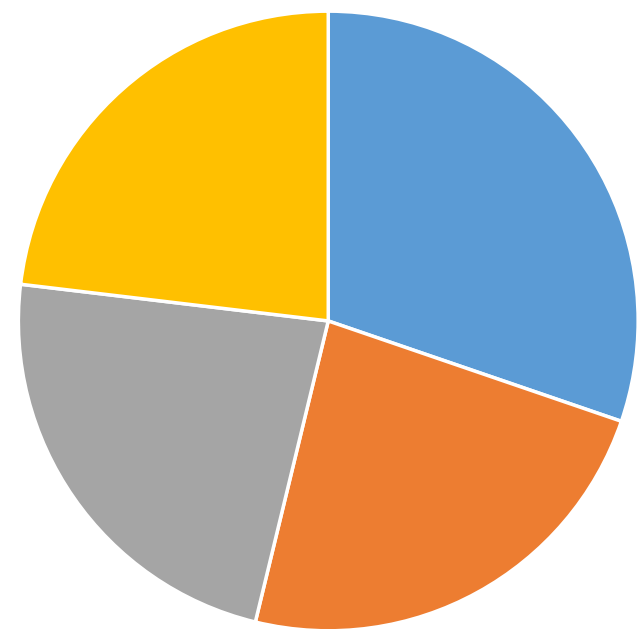

- Akhaltsikhe N1 School - Akhaltsikhe N3 School

घ Akhaltsikhe N2 School $\square$ Akhaltsikhe N6 School 


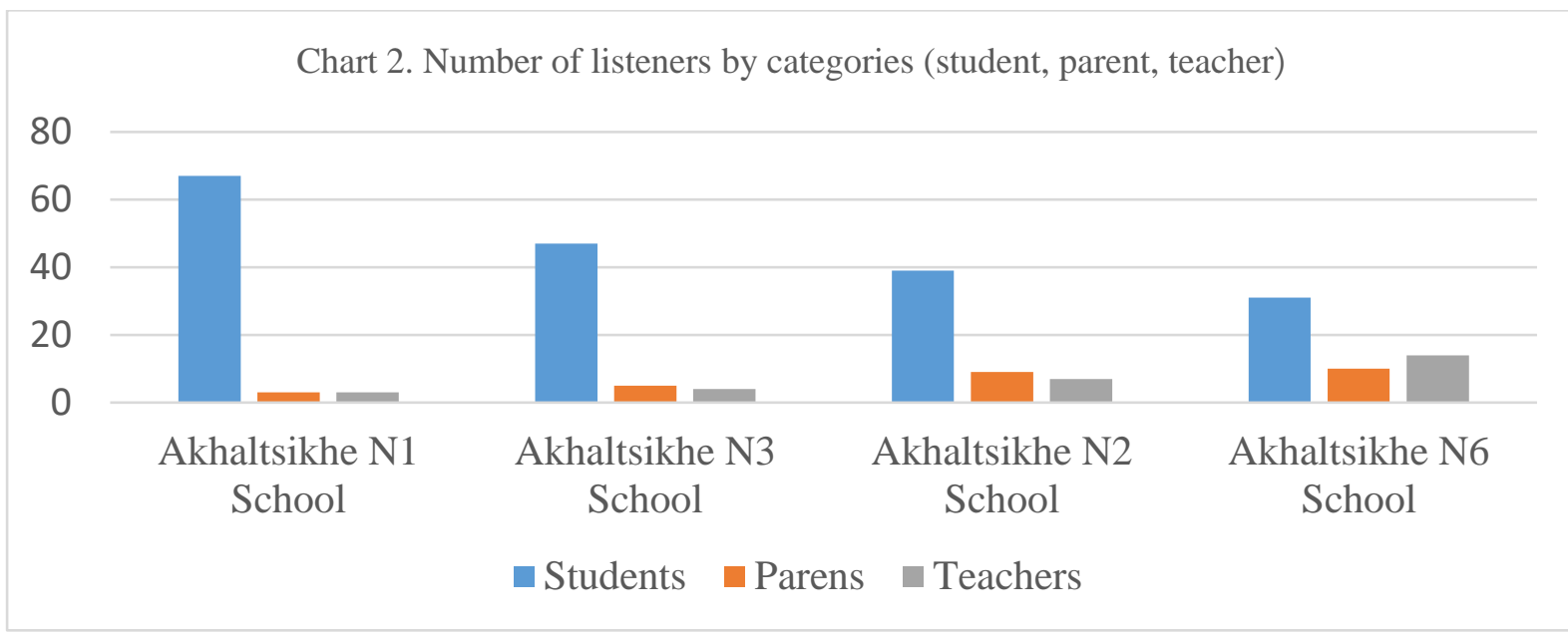

We should say that side by side with the public schools we held one meeting in a private school as well. It should be mentioned here that the level of the involvement of teachers in the workshops was even higher in the private school the proof of which is the number and quality of the works of the participants in the essay competition.

The workshops bore an interactive character although we had some separate time allocated for the question-and-answer session as well during which we provided answers to all the questions asked by the attendees. We should also mention it here that the workshop module was detailed down considering various activities within its scope, but the regulations imposed upon schools for the pandemic (the social distance to be kept between the students, prohibition of using the same things) excluded conduction of any group activities.

Upon the completion of the workshop the attendees filled up the questionnaire given to them for the training evaluation:

1. What was most important for you at the training?

2. About which of the issues would you like to deepen your knowledge?

3. Will you be able to use the knowledge acquired through the training in practice?

4. Please write your opinion concerning the training and the trainers. Any opinion will be accepted and appreciated.

Filling out the questionnaire was not mandatory. In case of Akhaltsikhe the workshop, attendees, as different from other regions, had no additional views in connection with the 
questionnaire filling up. Most activity in answering the questions asked by the questionnaire was shown by the students, parents and teachers of the Armenian school. At the same time, we had cases in other schools when a part of the training attendees refused to fill up the questionnaire, the other part demonstrating a scrupulous attitude toward answering on the questions meanwhile. When working on questionnaires after the completion of the workshops the trainees provided sincere answers to the questions given to them and underlined that the information on the process of European association in Georgia was new to them. Judging from the great interest the students as well as their parents and teachers showed toward the issue during the workshops clearly and vividly demonstrated the same. The beneficiaries express their willingness to put the knowledge obtained by them to use, for instance, to set up micro-enterprises complying with European standards for their family undertakings. Moreover, they link their future education to the prospect of benefiting from the share programs. Judging from this it is evident that the majority of the attendees of our workshops acquired the right understanding of what the EU support means for Georgia. On the side though, summing up the process and its outcomes from all points of view, we should mention the skeptical attitude demonstrated by a smaller part of the participants in the process believing that the $\mathrm{EU}$ is acting within its own interests willing to bring Georgia under its influence. It is a sad reality to respond to which actions are to be taken not only at the level of schools. Notwithstanding our project as well as the intense activities performed in the region by the information center concerning NATO and European Union, more information campaigns are required with the media taking an active part in them. Speaking of this, we will say it here that our work in Akhaltsikhe was broadcasted by both the local press * http://sknews.ge/ka/old/ 29872) and the local TV channels (tv9news, 2021). We are going to speak about the aforementioned problems in light of the goals and objectives of the "Triangle of European Studies" project as well as the results achieved in it. We see it reasonable that European studies become more active within the scope of the history and civil education lessons at school in order to ensure raising the awareness among the pupils. The supplementary reference material prepared within the frameworks of our project "The Process of EU-Association in Georgia" 
will have its good share in this. Immediately after the completion of the workshops, we heard the participants express their willingness for holding more of such meetings more frequently. Both the teachers and the students expressed their readiness for participation of similar type workshops in future. What we think in this respect is that side by side with all this it would be desirable to activate project designing working in schools and introduce the elements of informal education to get acquainted with the local undertakings set up with the EU-support, learn the specifics of their working and the existing benefits in their own region. This all would raise the level of knowledge/awareness as well as the sense of responsibility calling on them to take part in the introduction and implementation of the EU-association processes in Georgia. At the same time, we want to state it that while pursuing achievement of certain specific goals, it is not enough to just implement projects developed with the financing from various donor organizations. Despite the fact that the Ministry of Education, Science, Culture and Sports of Georgia provides its due support to us, their involvement in school activities in regions should be of a higher degree not in terms of the European Integration-related teachings but also in settling such issues as equipment of these schools with the required technical devices and technologies, ensuring the internet access for them, raising the teachers' skills of practical usage of information technologies which is partly in deficit in the schools we visited. There is one more very interesting issue that we want to speak about and that calls for attention indeed: when sending the contest essays receiving the materials from non-Georgian schools took a relevantly longer time. The reason was not the students' unwillingness to participate in such contests - on the contrary, the willingness expressed by them is quite high; the reason for this turned out to be that the students of these schools speak the Georgian language but their conversational language is not enough to let them write freely and due to the difficulties in their written communication these children commonly happen to be among the outsiders when it comes to different contests. This fact once again proves the necessity of teaching the state language in the non-Georgian schools on one side and at the same time shows the necessity to break the stereotype that if a student does not have the required competence in the writing skills he or she cannot freely demonstrate his/her opinions and 
judgments to the public. Such attitude on our part triggered some stimulus in these students and some of them are already writing their contest essays while the latter will on their part will further their knowledge and raise the level of their awareness in the EU-Georgia relations.

And last but not least, we want to deal with one more issue that was not envisaged by the introduction part of the training. The first part of the reference material and the training module prepared by us deals with the chronology of the EU-Georgia relations though the emphasis here is made on the major events having taken place in the course of preparing the Association Agreement. A part of the attendees of our workshops and meetings identified certain issues that were of interest to them and this should be necessarily taken into account when modifying the training modules in future. The issue deals with the role of the European Union in the 2008 Georgia-Russian war concerning which, the training attendees unfortunately have incorrect outlook. Therefore, we see it reasonable to enrich the material regarding this topic.

\section{TEESS in IDP's Abkhazia N3 Public School}

As said above, inadequate knowledge of the Georgian language is the main reason behind the scarcity of information available to the ethnic minorities in Georgia. A number of surveys taken in Georgia say that to fill the gap, they mostly rely on the Russian Media (Mikashavidze, 2016). Understandingly, it makes it difficult for them to comprehend what Georgia's association with Europe is all about and ultimately support the European integration policy. It is necessary to intensify strategic communication for better awareness of the issue. The ethnic minorities are now the target groups of various awareness raising projects. However, the prevalent mood regarding the European integration among the IDPs from Abkhazia and Tskhinvali region (South Ossetia) displaced as a result of the Russian occupation and armed conflicts has not been duly investigated, as yet. The IDPs speak Georgian, so getting information is no problem. The IDPs living in close knit communities and mostly marginalized. They get social allowances and humanitarian aid and are the target groups of the so-called integration projects (womenfundgeorgia, 2021). 
Public school \#3 in the capital Tbilisi with a large number of IDP pupils was made the target group of the "Erasmus +" Jean Monnet "Triangle Effect of European Studies at Schools" (TEESS) project. As the head master said, 100 IDP pupils and their families, mostly the Georgian displaced from Abkhazia live and study in the school facility.

44 pupils, 9 teachers and 6 parents attended the seminars. The atmosphere was charged with their memories of the war, the loved ones and the property they had lost and the inadequate living conditions and social allowance they have to come to terms with. Therefore, it is to no wonder that some of them, the teachers and even pupils, who had never lived in the USSR, sounded nostalgic about the Soviet Union where they were much better off. It shows that the pupils are largely influenced by the stories the adults tell them.

The participants agreed that the EU is Georgia's partner, but what they don't understand is why it has taken over 20 years for them to feel the benefits.

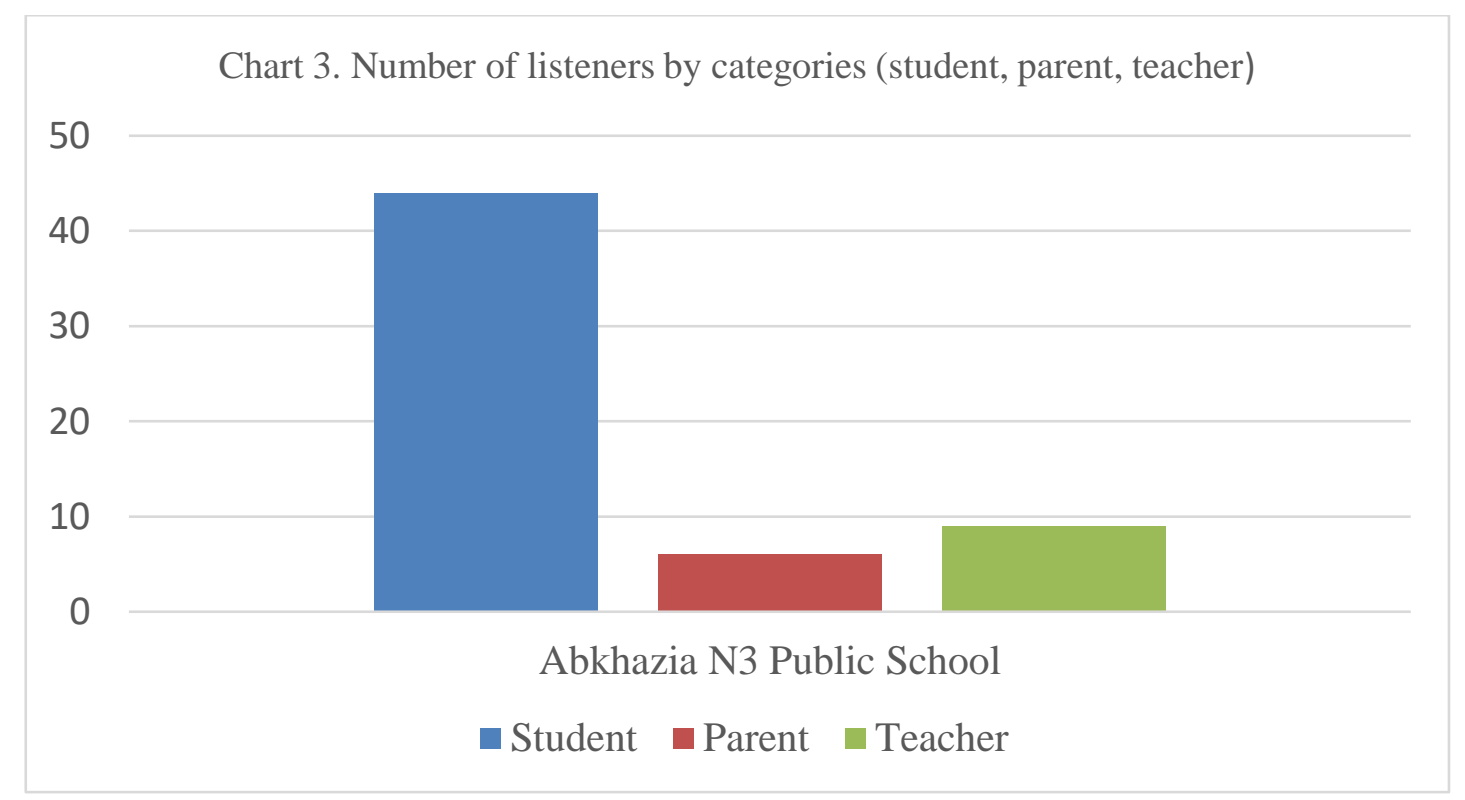

The strategies the trainers pursued was not denying or disregarding the concerns or antiEuropean mood of the participants but demonstrating the contrary facts, sources and statistics instead. For instance, when someone claims that the EU imposed single sex marriages on Georgia, the adequate answer is not the rhetoric about the personal freedom but neutralizing false information on Europe by referring to the Constitutions of several European states stating that the family is a registered union of a man and a woman. Only 
after a listener admits that he has been subjected to false information and believes what the trainer says, can we proceed with breaking down the other stereotypes.

The information on the EU support to Georgia is especially scarce. The people ask why they cannot feel the EU support in their daily lives. The meager technical equipment of the school housing such a vulnerable group is another problem creating obstacles in terms of the development of the younger generation.

For all the contrary views and heated discussions, even the most radical participants, both the teachers and pupils acknowledged that they had not known the truth about the EU, which is a positive indicator. It should be said though that this type seminars have to be staged regularly. Promotion of the EU-Georgia ties and trust-building will take continuous information supply and retraining of teachers. Hi-tech is to be available to the IDPs and namely, the schools they study at. And, that is the task of the Georgian Government and the authorities exiled from the breakaway regions, who retain their powers since the violation of the country's territorial integrity.

\section{TEESS in Marneuli Azerbaijani and Georgian-Russian Public Schools}

Working in Marneuli region densely populated with the ethnic Azeri proved to be especially interesting. The workshops supported by the Education Resource Center were held at Georgian-Russian public school \#2 and Azerbaijani public school \#3.

The one at Azerbaijani public school \#3 was attended by 55 pupils, 14 teachers and 41 parents. Incidentally, the parents, mostly mothers were the most active among the participants.

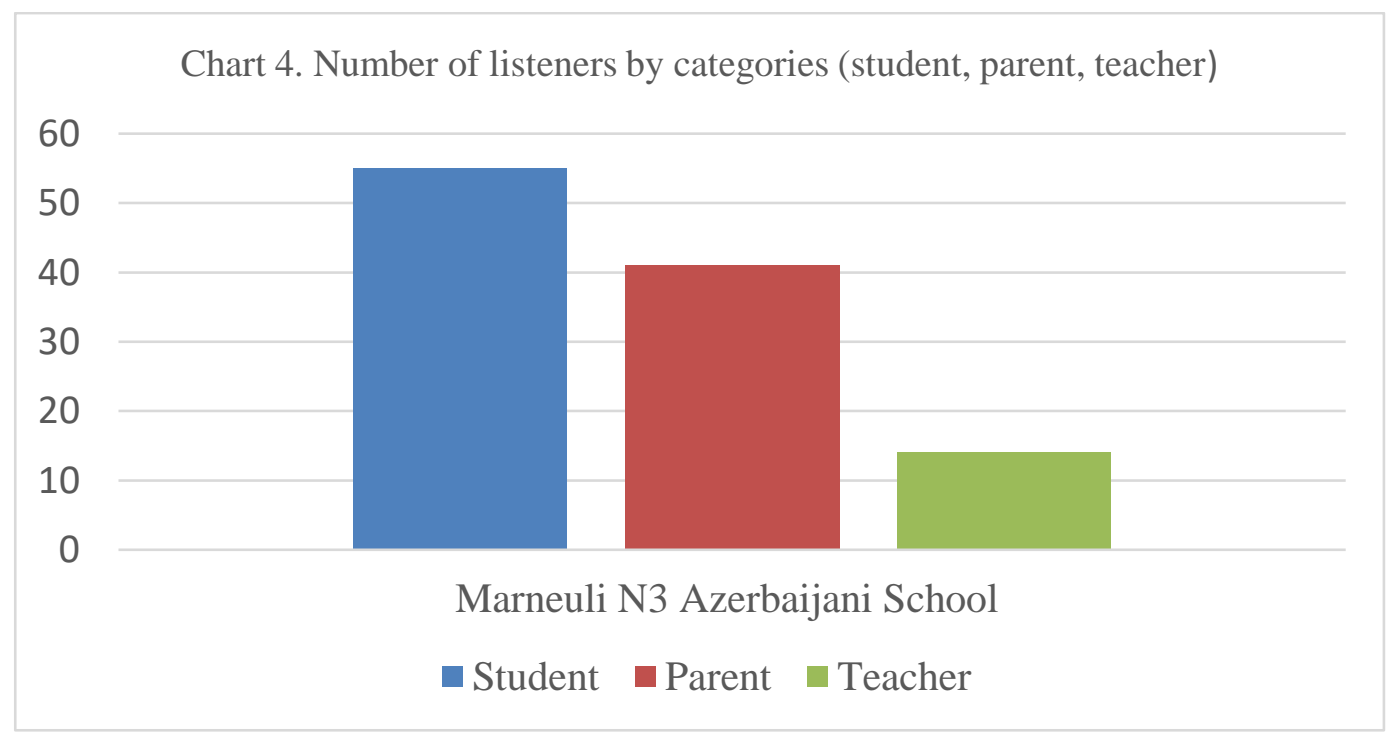


In terms of the pandemic regulations and the technical equipment except for a projector, the school is fit for appropriate instruction. Although the Georgian language and literature is taught and the teachers have a good command of the Georgian language, some of the pupils and most of the parents do not speak and understand it. So we had to hold the training in Russian or some of the pupils took on the part of the interpreters. However, on one occasion it was the other way round: the pupils did not understand Russian either, so we had to do the translation into Azeri language.

At Azerbaijani public school \#3 in Marneuli, they know next to nothing about the EU and its member states. To them the EU, NATO and the USA are about the same, something concerning. They believe that Georgia should maintain close ties with Azerbaijan, Russia and Turkey. To our question: "Turkey is a NATO member and an EU aspirant state, so, what about Georgia's relationships with it?" they retorted that Turkey was never going to be admitted to the EU and it was all a part of the Western propaganda campaign! They think that the Western countries are against the Azeri-Turkish progress, and it was Turkey and Russia that were instrumental in the settlement of the Azeri-Armenian conflict over Nagorno-Karabakh and supported Azerbaijan in restoration of its territorial integrity.

Understandingly, they know but little about the EU projects implemented in the Georgia's Lowe Kartli region, namely in Marneuli Municipality. Many of the parents, pupils and even teachers did not know anything about the Erasmus+ programs and as they learned that those are educational programs for young people, some of the pupils sounded willing to get involved apparently for purely practical reasons, such as employment and financial stability. It was during the trainings that the attendees learned about AA/DCFTA holding promise of export of agricultural produce from the Marneuli region to the EU market. In their words, they would pay more attention to the opportunity and make a good use of it.

The most striking problem in the said and presumably the other ethnic minority public schools is poor knowledge of Georgia's official language, scarcity of information on the political, economic and cultural developments in the country and total unawareness of Georgia's foreign policy priorities and its strive towards the West. Many of them even do 
not know what the visa-free travel is and whether it is a benefit to the Georgian citizens. They were surprised to learn that the Georgian passport holders were free to travel in the Schengen area. Some of them even asked whether it was true. They made no secret that they watch only the Azeri and Russian TV channels.

For all our efforts to provide them with as much information as possible on the EU and the benefits Georgia gets, they were skeptical. Some of the participants did not even sign the attendance register and refused give feedback. When we asked "Why", they said the signature could be used for the Covid vaccination. The project team did their best to explain that it was wrong.

Regardless of the aforesaid difficulties, the trainings proved to be productive for dozens of children got the information on the EU and Georgia-EU relationships. The pupils promised to look for more information in the Internet. The teachers realized they had to work harder in that direction. Some of the parents realized the prospects the EU opened up for their children. As to the trainers, we saw there still was a lot of work to do for the pupils to perceive themselves as truly Georgian citizens and realize the challenges facing the country. Also, it is clear that merely the trainings will not do and tackling the above problems calls for joint efforts of the NGOs and State agencies, such as the Education Ministry, local government (town hall, city assembly, educational resource center), as well as more intensive communication between the Western Embassies in Georgia and the locals.

It should be noted that we got a somewhat different picture at Georgian-Russian public school \#2 in Marneuli: the pupils are much better informed where the EU and the European values are concerned. The school maintains close ties with regional office of "The NATO and EU Information Center". Moreover, the Office head teaches the Civic Education course there. Over 100 pupils, teachers and parents attended the TEESS project workshops. 


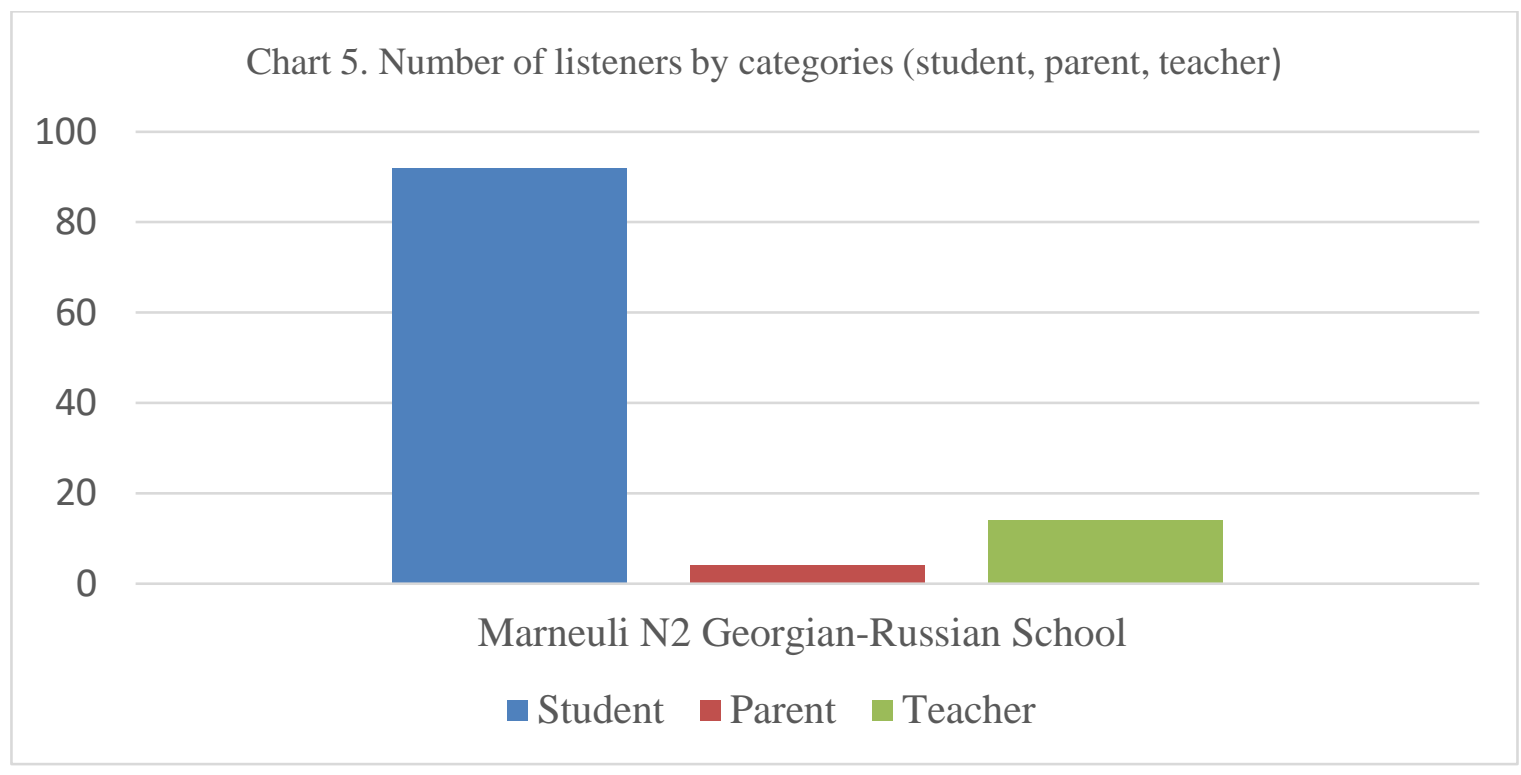

Several sessions were dedicated to the EU history, Georgia-EU Association Agreement etc. The answers to our questions showed the interest to the issues and support to Georgia's integration into Europe. Not only the history and civic education teachers but those of geography, Georgian and foreign language teachers voiced their readiness for the European studies at the school. They said that jointly with the BA students of the European Studies of the School of Humanities and Social Sciences at the Caucasus University and the academic staff they would like to implement the projects involving the European values and, to this end, use the manual published within the frameworks of the project. Most of the pupils of the school are ethnic Azeri, have a good command of the Georgian language and associate Georgia's future with Europe. They showed keen interest to the issue and entered "I Saw Europe in Georgia" competition of essays. As against their fellow pupils of the other school, they did not hesitate to fill out the training assessment questionnaire. We are ready to work harder where the Europe-related information supply to the residents of the Marneuli region is concerned. We hope that the public interest to the EU-Georgia association is going to be galvanized by the local Media: TV (facebook, 2021 (24news, 2021) coverage of the project in the Georgian and the Azeri languages.

After the trainings in Marneuli, the NATO and EU Information Center in Georgia (LEPL) at the Ministry of Foreign Affairs of Georgia showed interest to Jean Monnet “Triangle Effect of European Studies at Schools" (TEESS) Erasmus+ Project of the Caucasus 
University, and during "The 2021 European Days" jointly with the Project team, arranged the ZOOM presentation of the textbook "European Association Process in Georgia" for the teachers of the regions. At the presentation, the project team spoke in detail about the structure, content and application of the manual. It would be no overstatement to say that TEESS broke through the school and University limits and resulted in productive collaboration with the NATO and EU Information Center in Georgia and the National Center for Professional Advancement of Teachers, which on its part, arranged an online presentation of the said manual for teachers across Georgia. Also, at the Caucasus University, the Project team met with the Civic Education Teachers' Forum and members of the History Teachers Association. We suppose the collaboration is going to provide more opportunities in terms of implementation of the EU-related projects. Finally, we wish to acknowledge the Georgian-Armenian Union for its support to our work at the Armenian schools.

\section{"I Saw Europe in Georgia" Essay Competition}

"I Saw Europe in Georgia" competition of essays roused plenty of the pupils' interest. Understandingly, not all the pupils entered the competition but most of them were eager to know more about Georgia's aspiration for EU membership. Scores of pupils of the Georgian, Russian, Armenian and Azerbaijani schools from across Georgia got involved in the competition. For all the concerns of the non-Georgian participants to write essays in Georgian, the results confirmed that the project team did the right thing by staging the workshops in the Georgian language. The pupils asked for the Georgian teachers' consultations and ultimate the results were impressive enough: the essays of the pupils of the Armenian public school \#3 in the town of Akhaltsikhe and Armenian public school \#104 in the capital Tbilisi stood out in terms of their content and calligraphy. The essays were assessed by the senior BA students of the European Studies of the School of Humanities and Social Sciences at the Caucasus University. Checking the essays was a good hands-on work for the University students. Their arguments while picking out the best essays were well-grounded. The essays made the pupils' belief in Georgia's European 
prospects evident. The winners of the 6 competing schools were awarded with the certificates, books etc. The Project team acknowledged the teachers for their use of the manual in the instruction. On their part, they voiced their proposals as to how they are going to introduce the European values during the classes. We have the author of the best proposals. The practical implementation of the plan offered by the civic education teacher from Marneuli N2 Georgian-Russian School, will further ensure the sustainability and continuity of the results obtained by the project. The interest and participation of the Forum of Civic Education Teachers in project "Round table" can also be a guarantee of this.

\section{Conclusions}

Based on the project assessment, we suggest countering the increasing anti-Western propaganda by a regular, intensive public dialog to ensure creation of a positive popular mood where Georgia's European integration is concerned. For all the problems created by the Coronavirus pandemic both in Georgia and the rest of the world, we managed to implement the project and achieved its objectives. There is a lot of work to do, though. Insufficient awareness of the European values and poor command of the Georgian language among the ethnic minorities is still a challenge. While carrying out the project, we saw clearly the interest in Georgia's integration into Europe not only at the beneficiary schools but the other secondary schools, as well. It was their independent decision to introduce a civic education manual. "Tsiskari", the Georgian-Italian school has come up as the frontrunner, which means that the text book is now available across the national educational system. The outcome of the project stimulates us to implement similar projects in various Georgian regions. To this end, the support of the Ministry of Education and Science and sharing the experience gained in the implementation of TEESS project is essential. We believe that the interest in Europe is going to be stimulated by a wider application of the EU Erasmus in Schools project and national competitions involving allthe-level pupils. 


\section{References}

Chelidze G., Kardava E., Bragvadze Z., (2020). European Association Process in Georgia, Handbook for History and Civic Education Teachers, Caucasus University Publishing House, Tbilisi, 2020

Citizenship, (2018-2024). Basic Stage Standard, http://ncp.ge/ge/curriculum/satestoseqtsia/akhali-sastsavlo-gegmebi-2018-2024/sabazo-safekhuri-vi-ix-klasebi-proeqtisadjaro-gankhilvistvis (access 21.05.2021)

Fassoulas, (2016). Fassoulas Petros, Learning EU at School' on the ground: the work of the European Movement network,

Mikashavidze, (2016). Mikashavidze Maia, Enthnic Minorities in Georgia: From Media Involvement to Strengthening, Policy Document, 2016 https://www.osgf.ge/files/2016/EU\%20publication/Angarishi_A4_Media_GEO. pdf (access 21.05.2021)

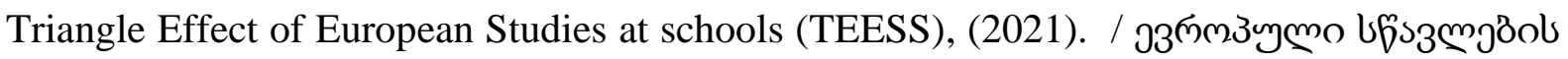

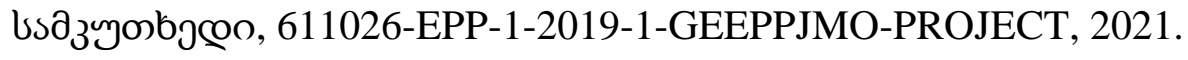

24news, (2021). https://24news.ge/read/id/47642?fbclid=IwAR01-8xiPnqA8fFeZBKa8gbHEibfh7a V7I7zIx7H_PI-OT3nR8iQ4j1nLg)

cu.edu.ge, (2021). https://cu.edu.ge/files/gallery/Grant\%20Projects/2020/ broshura-geoBolo.pdf).

facebook, (2021). https://www.facebook.com/watch/?v=4438599982822825

Sknews, (2021). http://sknews.ge/ka/old/29872

textbook, (2021). https://cu.edu.ge/grant-projects/cu-grant-projects-news/european-association tpdc, (2021). http://tpdc.ge/geo/news/706

tv9news, (2021). https://tv9news.ge/ka/akhali-ambebi/ganathleba/article/22358-akhalcikheshievrokavshirthan-asocirebis-themaze-treningebi-tardeba?fbclid=IwAR15xquWJP3vj1LH-wbHg1QozGAfP-JA91PeBkpCWhxgk7FDMkaxejOZAs)

Womenfundgeorgia, (2021). https://womenfundgeorgia.org/en/News/AllNews /2133 www.epfound.ge - Unfortunately, the website has been temporarily inaccessible since 11.03.2021)

http://sknews.ge/ka/old/29872 (access 21.05.2021) 

„Triangle Effect of European Studies at Schools“ (TEESS)

https://cu.edu.ge/grant-projects/cu-grant-projects-news/european-association (access 21.05. 2021)

https://europeanmovement.eu/learning-eu-at-school-on-the-ground-the-work-of-theeuropean-movement-network-2/ (access 21.05.2021)

https://tv9news.ge/ka/akhali-ambebi/ganathleba/article/22358-akhalcikheshievrokavshirthan-asocirebis-themaze-treningebi-tardeba?fbclid=IwAR15xquWJP3vj1LH-wbHg1QozGAfP-JA91PeBkpCWhxgk7FDMkaxejOZAs (access 21. $05.2021)$

https://womenfundgeorgia.org/en/News/AllNews/2133 (access 21.05.2021) 